\title{
INTÉRET DE L'UTILISATION D'UN MUTANT FROID \\ PRODUIT EN CULTURE CELLULAIRE Dans LA VAccination Contre la peste porcine classigue
}

\author{
J. M. AYNAUD et J. ASSO \\ Station de Recherches de Virologie et d'Immunologie, I. N. R. A., \\ Route de Thiverval, 78 - Thiverval-Grignon
}

\section{RÉSUMÉ}

A l'aide des techniques d'immunofluorescence, des mutants non pathogènes du virus de la peste porcine ont été isolés après sélection en culture cellulaire à $29-30^{\circ}$. La mise en évidence des marqueurs génétiques in vitro en relation avec le pouvoir pathogène permet de distinguer facilement ces mutants des souches sauvages virulentes:

A la différence des virus sauvages virulents qui sont chauds (température optimale de $4^{\circ}$ ) et solides (résistants à $5^{\circ}$ ), les mutants non pathogènes isolés à 29-30 sont froids (température optimale de $30-33^{\circ}$ ) et fragiles (inactivés à $5^{6}$ o C) .

Ces mutants sont dépourvus de pouvoir pathogène résiduel. Inoculés à des porcelets traités ou non avec des immunodépresseurs, ces mutants sont incapables de provoquer de l'hyperthermie ou des signes cliniques.

Ces mutants inđuisent une bonne immunité permettant aux animaux de résister à l'inoculation d'épreuve avec le virus sauvage.

Présentant des garanties d'innocuité et d'efficacité, ces virus peuvent être utilisés comme vaccins vivants en absence de sérum hyperimmun homologue. Ce qui présente de grands avantages d'ordre économique et pratique. 


\author{
SUMMARY \\ INTEREST OF USING A COLD MUTANT REARED IN CELLULAR CULTURE \\ FOR THE VACCINATION AGAINST USUAL SWINE FEVER
}

Non pathogenic mutants of the swine fever virus were isolated by means of immuno-fluorescence techniques after selection in cellular culture at $29-30^{\circ}$. These mutants may be easily differentiated from the virulent savage strains by means of $i n$ vitro determination of the genetic markers related with the pathogenic capacity :

The virulent savage virus is hot (optimum temperature at $4^{\circ}{ }^{\circ} \mathrm{C}$ ) and solid (resistant at $56^{\circ} \mathrm{C}$ ) whereas the non pathogenic mutant isolate at $29-30^{\circ} \mathrm{C}$ is cold (optimum temperature at $30-33^{\circ} \mathrm{C}$ ) and fragile (inactivated at $56^{\circ} \mathrm{C}$ ).

The mutants have no residual pathogenic capacity and when they are inoculated into piglets treated or not with immuno-depressors, they are not able to provoke hyperthermia or clinical symptomes.

Because of the immunity obtained by means of these mutants, the animals resist to the test inoculation with the savage virus.

Offering a guaranty of innocuousness and efficiency, these virus may be used as alive vaccines without hyperimmune homologous serum, which is a great economic and practical advantage.

\title{
IMPORTANCE EN FRANCE DE LA COLIBACILLOSE DU PORCELET NOUVEAU-Né
}

\author{
L. RENAULT, C. MAIRE et J. VAISSAIRE \\ Établissements Sanders, 91 - Juvisy-sur-Orge
}

\section{RÉSUMÉ}

La recherche systématique des souches pathogènes d'Escherichia coli, par la mise en évidence de leur pouvoir hémolytique, de leur pouvoir agglutinogène direct en présence de sérums anticap. sulaires et de leur pouvoir pathogène pour la souris, permet de constater que la colibacillose est une des principales affections digestives, sinon la principale, du porcelet nouveau-né. Sur 235 élevages présentant des troubles, $46,8 \mathrm{p}$. Ioo d'entre eux étaient atteints de cette maladie pour une période allant de 1966 aux trois premiers trimestres $197^{\circ}$.

Un examen bactériologique précis doit permettre la mise en place d'un traitement antibio.tique efficace ou d'un vaccin approprié à l'élevage, dans la mesure où il portera sur un grand nombre de porcelets et de matières fécales des truies gestantes. Ces mesures ne pourront bien entendu remplacer, dans aucun cas, les mesures classiques d'hygiène concernant les animaux et les bâtiments. 